Stephanie Schwalm*, Tankica Maneva Timcheva, Iuliia Filipenko, Mahsa Ebadi, Lotte P. Hofmann, Uwe Zangemeister-Wittke, Josef Pfeilschifter and Andrea Huwiler

\title{
Sphingosine kinase 2 deficiency increases proliferation and migration of renal mouse mesangial cells and fibroblasts
}

\begin{abstract}
Both of the sphingosine kinase (SK) subtypes SK-1 and SK-2 catalyze the production of the bioactive lipid molecule sphingosine 1-phosphate (S1P). However, the subtype-specific cellular functions are largely unknown. In this study, we investigated the cellular function of SK-2 in primary mouse renal mesangial cells (mMC) and embryonic fibroblasts (MEF) from wild-type $\mathrm{C} 57 \mathrm{BL} / 6$ or SK-2 knockout (SK2ko) mice. We found that SK2ko cells displayed a significantly higher proliferative and migratory activity when compared to wild-type cells, with concomitant increased cellular activities of the classical extracellular signal regulated kinase (ERK) and PI3K/Akt cascades, and of the small G protein RhoA. Furthermore, we detected an upregulation of SK-1 protein and S1P receptor mRNA expression in SK-2ko cells. The MEK inhibitor U0126 and the S1P $\mathrm{P}_{1 / 3}$ receptor antagonist VPC23019 blocked the increased migration of SK-2ko cells. Additionally, $\mathrm{S1P}_{3} \mathrm{ko}$ mesangial cells showed a reduced proliferative behavior and reduced migration rate upon S1P stimulation, suggesting a crucial involvement of the $\mathrm{S}_{1} \mathrm{P}_{3}$ receptor. In summary, our data demonstrate that SK-2 exerts suppressive effects on cell growth and migration in renal mesangial cells and fibroblasts, and that therapeutic targeting of SKs for treating proliferative diseases requires subtype-selective inhibitors.
\end{abstract}

*Corresponding author: Stephanie Schwalm, Pharmazentrum Frankfurt/ZAFES, Klinikum der Johann Wolfgang Goethe-Universität, Theodor-Stern-Kai 7, D-60590 Frankfurt am Main, Germany; and Institute of Pharmacology, University of Bern, Friedbühlstrasse 49, CH-3010 Bern, Switzerland, e-mail: S.Schwalm@med.uni-frankfurt.de Tankica Maneva Timcheva, Iuliia Filipenko, Uwe ZangemeisterWittke and Andrea Huwiler: Institute of Pharmacology, University of Bern, Friedbühlstrasse 49, CH-3010 Bern, Switzerland Mahsa Ebadi and Josef Pfeilschifter: Pharmazentrum Frankfurt/ ZAFES, Klinikum der Johann Wolfgang Goethe-Universität, TheodorStern-Kai 7, D-60590 Frankfurt am Main, Germany Lotte P. Hofmann: Pharmazentrum Frankfurt/ZAFES, Klinikum der Johann Wolfgang Goethe-Universität, Theodor-Stern-Kai 7, D-60590 Frankfurt am Main, Germany; and Institute of Pharmacology, University of Bern, Friedbühlstrasse 49, CH-3010 Bern, Switzerland
Keywords: fibroblasts; migration; proliferation; renal mesangial cells; sphingosine 1-phosphate; sphingosine kinase.

DOI 10.1515/hsz-2014-0289

Received December 1, 2014; accepted March 2, 2015; previously published online March 9, 2015

\section{Introduction}

One major function of sphingolipids is the structural support of cellular membranes. However, it has become clear that some sphingolipid subspecies also exert important signaling functions and thereby regulate a variety of physiological and pathophysiological processes including cell growth and differentiation, cell survival, migration and inflammation (Huwiler et al., 2000; French et al., 2003; Huwiler and Pfeilschifter, 2006; Kunkel et al., 2013).

In particular, ceramide and sphingosine 1-phosphate (S1P) have attracted a lot of interest, as they build a cellular rheostat that finally determines whether a cell grows or dies (Huwiler et al., 2000; Huwiler and Pfeilschifter, 2006; Kunkel et al., 2013). These two lipids are rapidly interconverted by the action of two enzyme classes, i.e., the ceramidases that deacylate ceramide to form sphingosine, and sphingosine kinases (SK) that phosphorylate sphingosine to form S1P.

So far, two subtypes of, SK, SK-1 and SK-2, have been cloned and characterized (Alemany et al., 2007). Both subtypes of SK are ubiquitously expressed in most tissues, but show differential subcellular localizations (Alemany et al., 2007). Although both enzymes catalyze the same reaction and produce S1P, the physiological or pathophysiological functions of the two subtypes and variants are presently still unclear. Many studies have addressed the functions of SK-1 and there is a broad consent on its key function in cell proliferation and migration (Shida et al., 2008; Pyne and Pyne, 2010). This is further supported by 
studies showing an upregulation of SK-1 mRNA in several cancer types (French et al., 2003, 2006; for review see Pyne and Pyne, 2010). Moreover, an increased SK-1 expression correlates with poor survival of breast cancer patients (Ruckhäberle et al., 2008).

In contrast, SK-2 has been appointed a rather pro-apoptotic function based on cellular transfection experiments (Liu et al., 2003). SK-2 contains a BH3 domain that can interact with $\mathrm{Bcl}-\mathrm{X}_{\mathrm{L}}$ and thereby inhibit the protective potential of $\mathrm{Bcl}-\mathrm{X}_{\mathrm{L}}$ consequently resulting in enhanced apoptosis. Additionally, the overexpression of SK-2 in various murine and human cell lines resulted in reduced DNA synthesis (Igarashi et al., 2003; Okada et al., 2005). In line with this, previous data on mouse mesangial cells isolated from SK-2 knockout mice revealed that lack of SK-2 protects from stress-induced apoptosis (Hofmann et al., 2008). However, recently it was suggested that also SK-2 positively contributes to cancer cell growth, as the putative selective SK-2 inhibitor ABC294640 reduced cancer cell growth in vitro and in a tumor xenograft model in mice (French et al., 2010).

In the present study, we used mouse renal mesangial cells (mMC) and mouse embryonic fibroblasts (MEF) isolated from SK-2 deficient mice or siRNA against SK-2, and investigated changes in cellular responses such as cell migration and proliferation. We show that the loss of SK-2 correlates with a higher proliferative and migratory phenotype of the cells. Conversely, when using the putative SK-2 inhibitor ABC294640, a reduced proliferation rate of renal mesangial cells was seen, which, surprisingly, was also detected in SK-2ko cells, suggesting that this compound is non-specific and affects cell proliferation unrelated to SK-2 inhibition. On the molecular level, we found that SK-2 depleted cells have a compensatory upregulated SK-1 protein expression, an increased activity of the small $\mathrm{G}$ protein RhoA, increased activities of the classical ERK and PI3K/Akt cascades, and a strongly upregulated $\mathrm{S}_{3} \mathrm{P}_{3}$ receptor expression. All these alterations may contribute to the observed increased cell migration and proliferation.

\section{Results}

\section{Loss of SK-2 increases proliferation and migration of mouse mesangial cells and fibroblasts}

As the cellular function of SK-2 is still poorly understood, we used renal mesangial cells and MEF isolated from either wild-type mice or SK-2 gene deficient mice to unravel a possible contribution of SK-2 to physiological or pathophysiological cell responses. First, renal mesangial cells (Figure 1A) and MEF (Figure 1B) were characterized for SK-2 protein expression by Western blot analysis. SK-2 runs as an approximately $68 \mathrm{kDa}$ band in SDS-PAGE. In primary cultures of mMCs or MEFs isolated from SK-2 knockout (ko) mice, this band was abolished, confirming the complete knockout of the gene. The antibody additionally recognized a band at $43 \mathrm{kDa}$, which was not reduced in the SK-2 depleted cells, thus suggesting a likely unspecific staining.

Under normal cell culture conditions, it became obvious that SK-2ko cells proliferated much faster than the corresponding wild-type cells. To confirm thatDNA synthesis was enhanced, $\left[{ }^{3} \mathrm{H}\right]$ thymidine incorporation was measured in cells plated in equal numbers. As seen in Figure $2 \mathrm{~A}$, over the time period of 2 days, SK-2ko mMC showed a several-fold increase of DNA synthesis. A similar increase was also seen in SK-2ko MEFs when compared to the wildtype cells (Figure 2B) and in mesangial cells transiently transfected with siRNA against SK-2 (Figure 2C). Additionally, we tested the putative SK-2 inhibitor ABC294640 on renal mesangial cell proliferation and detected a reduction of cell proliferation at a concentration of $30 \mu \mathrm{M}$ and even more pronounced at $100 \mu \mathrm{M}$. Strikingly, the same effect was obtained when using SK-2 knockout mesangial cells (Figure 2D, grey bars) suggesting an unspecific effect of ABC294640 not related to SK-2 inhibition.

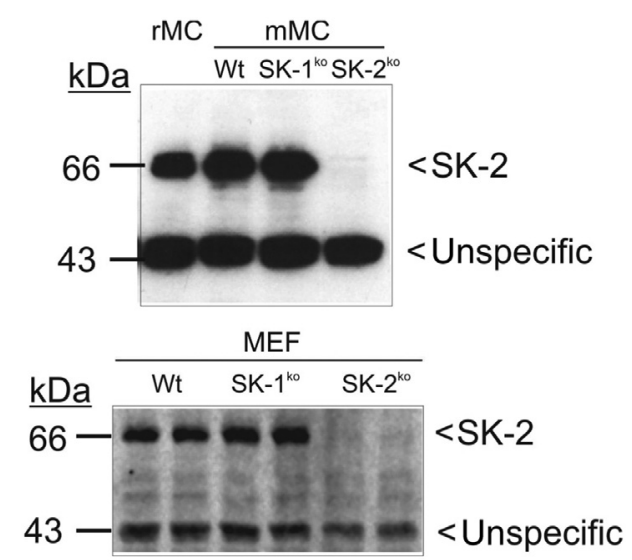

Figure 1: Sphingosine kinase 2 protein expression in mouse renal mesangial cells and embryonic fibroblasts.

Protein lysates of quiescent mouse mesangial cells (mMC) and mouse embryonic fibroblasts (MEF) isolated from either C57BL/6 mice (Wt), SK-1 deficient mice (SK-1ko), SK-2 deficient mice (SK-2ko) or rat mesangial cells (rMC) were separated by SDS-PAGE, transferred to nitrocellulose and subjected to Western blot analysis using a specific antibody against mouse SK-2 at a dilution of 1:1000. Bands were visualized by the ECL method according to the manufacturer's instructions. 

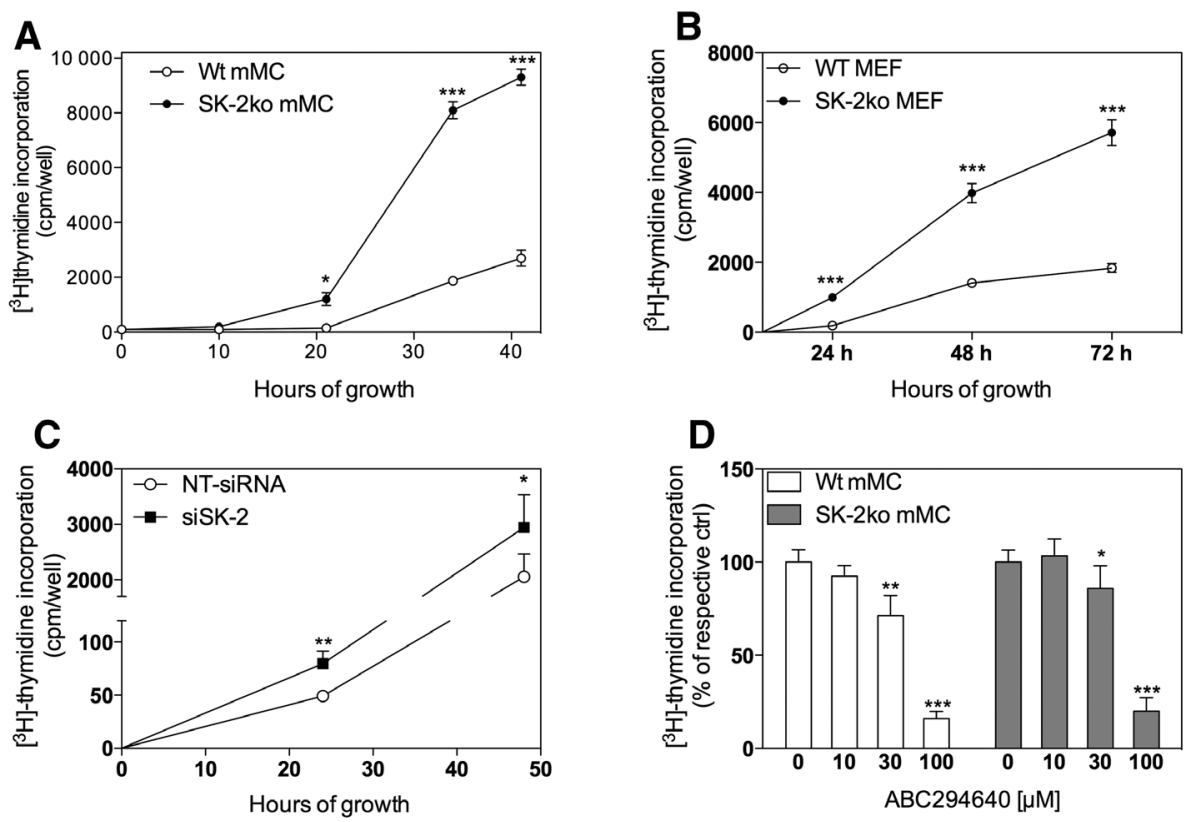

Figure 2: Effect of SK-2 deficiency on proliferation of mouse mesangial cells and embryonic fibroblasts.

$10^{4}$ mouse mesangial cells (A, C, D, mMC) or mouse embryonic fibroblasts (B, MEF) isolated from either wild-type C57BL/6 mice (Wt, open circles) or SK-2 deficient mice (SK-2ko, closed circles) or mesangial cells transiently transfected with a non-target siRNA (C, NT-siRNA, open circles) or siRNA against SK-2 (C, siSK-2, closed circles) were plated and grown for the indicated time periods in growth medium supplemented with [ $\left.{ }^{3} \mathrm{H}\right]$ thymidine alone $(\mathrm{A}-\mathrm{C})$ or with the indicated concentrations of $\mathrm{ABC} 294640$ for $24 \mathrm{~h}(\mathrm{D})$ and processed as described in the Methods section. [ ${ }^{3} \mathrm{H}$ ]thymidine incorporated into DNA was measured in a $\beta$-counter. Data are expressed as $\mathrm{cpm} /$ well $(\mathrm{A}, \mathrm{B})$ or \% of control (C, D) and are mean $\pm \mathrm{SD}(\mathrm{n}=3-5) .{ }^{*} p<0.05,{ }^{\star \star} p<0.01,{ }^{\star \star *} p<0.001$ considered statistically significant compared to the corresponding Wt values $(A, B)$ or to the respective control values $(C, D)$.

In a next step, the migratory capacity of cells was determined. To this end, either an adapted Boyden chamber assay (Figure 3A) or a scratch assay (Figure 3B-G) was performed. In the adapted Boyden chamber assay, equal numbers of cells were plated onto a Transwell filter with $8 \mu \mathrm{m}$ pores and allowed to migrate through the filter for $7 \mathrm{~h}$. Thereafter, non-migrated cells were scraped away from the surface of the filter and cells that had migrated into the filter were visualized by DAPI staining. Figure 3A shows again that SK-2ko cells migrated faster than wildtype cells. Another method to measure cell migration is the so-called scratch assay. However, this assay cannot discriminate between migrating cells and proliferating cells and results reflect more a mixture of migration and proliferation. Therefore, to minimize the amount of cell proliferation, we performed this assay under strongly reduced serum concentrations $[1 \%$ fetal bovine serum (FBS)]. Again, our data reveal that SK-2ko mesangial cells (Figure 3B, right panels) and SK-2ko MEFs (Figure 3D, right panels) or cells transfected with siRNA against SK-2 (Figure 3F, right panels) migrated faster than the corresponding wild-type (Figure 3B and D, left panels) or nontarget siRNA transfected cells (Figure 3F, left panels).

\section{Loss of SK-2 activates ERK and Akt signaling in mesangial cells and fibroblasts}

We further investigated whether the increased proliferation and migration of SK-2ko cells was the result of specifically activated signaling cascades, such as the well-known proliferation and migration regulating classical mitogen-activated protein kinase (MAPK)/ERK cascade. To this end, Western blot analyses of mesangial cell lysates were performed by staining for phosphorylated and thus activated p44-ERK1 and p42-ERK2. Quiescent wild-type cells that were incubated for $6 \mathrm{~h}$ in a very low serum concentration ( $1 \%$ FBS) expressed low levels of phospho-ERK1/2, whereas the SK-2ko cells showed a significantly increased ERK1/2 phosphorylation (Figure 4A). Another signaling cascade that has been linked to cell growth and survival, but also to cell migration, is the PI3K/Akt cascade (Vivanco and Sawyers, 2002). We found that also phospho-Akt was enhanced in SK-2ko mesangial cells (Figure 4B), and similar data were obtained in MEFs (Figure $4 \mathrm{C}$ and D). All these data suggest that in SK-2ko cells the classical MAPK/ERK and the PI3K/Akt cascades are hyperactivated. 


\section{A}

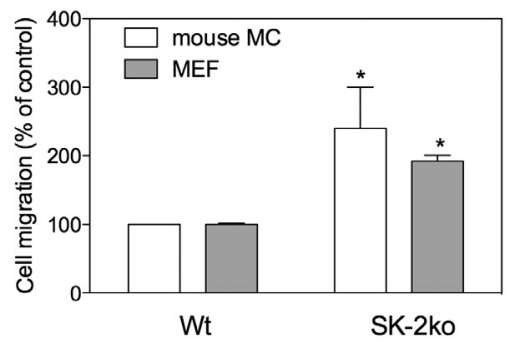

B
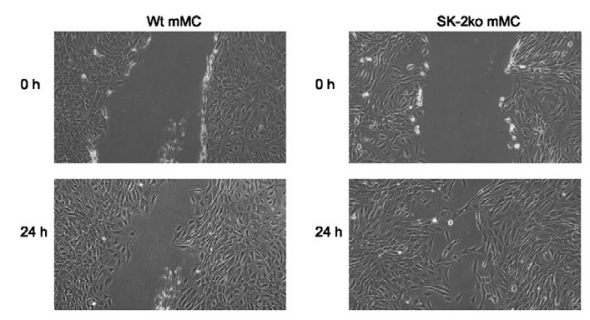

\section{C}
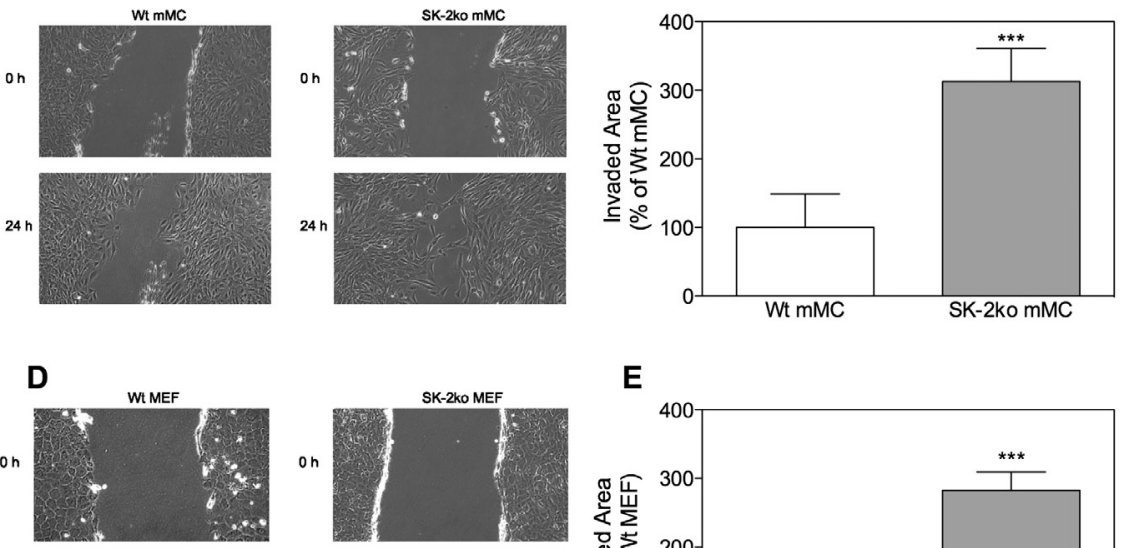

E
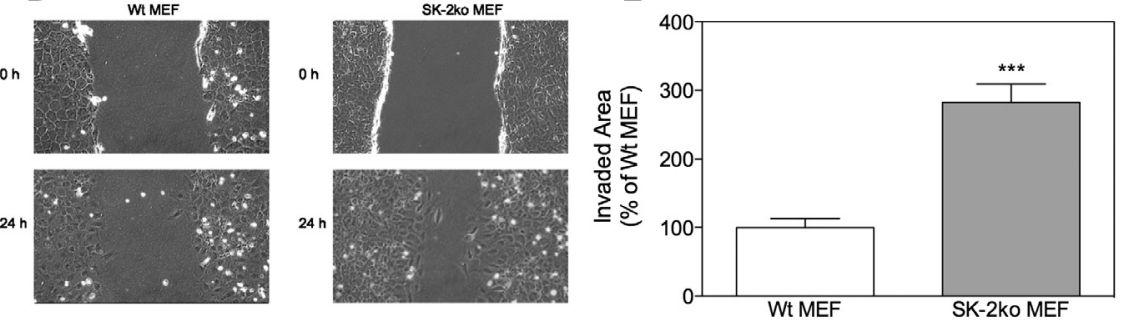

G
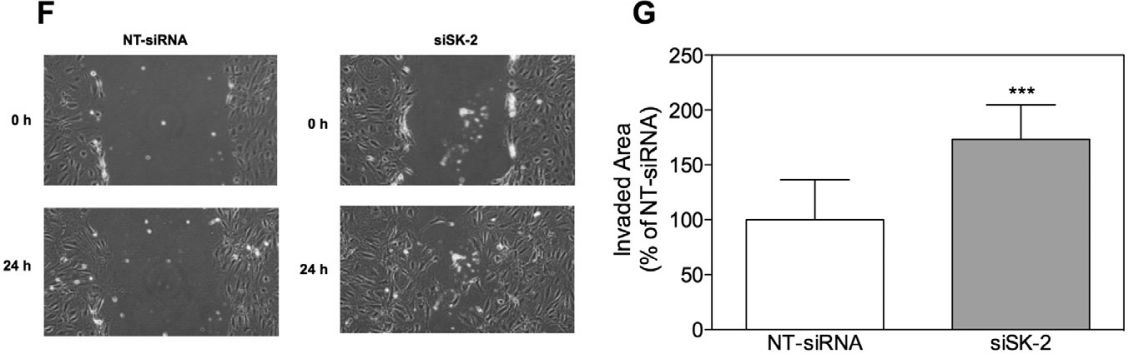

Figure 3: Effect of SK-2 deficiency on migration of mouse mesangial cells and embryonic fibroblasts.

(A) $10^{5}$ serum-starved mouse mesangial cells (open columns) or mouse embryonic fibroblasts (closed columns) isolated from either wild-type (Wt) or SK-2 deficient mice (SK-2ko) were subcultured onto Transwell filters and allowed to migrate for $7 \mathrm{~h}$. Migrated cells were determined as described in the Methods section. (B-G) Quiescent wild-type (Wt) or SK-2 deficient (SK-2ko) mesangial cells (B, C, mMC), quiescent mouse embryonic fibroblasts (D, E, MEF) or transiently transfected mouse mesangial cells with either non-target siRNA (F, G, NT-siRNA) or siRNA against SK-2 (F, G, siSK-2) were subjected to a scratch and then allowed to recover for $24 \mathrm{~h}$ in DMEM containing $1 \%$ FBS. Light microscopy pictures were taken at time point $0 \mathrm{~h}$ and $24 \mathrm{~h}$ after the scratch (B, D, F show representative samples). Data in $\mathrm{C}, \mathrm{E}, \mathrm{G}$ show the quantification of the scratch area after $24 \mathrm{~h}$ and are expressed as invaded area from time point $0 \mathrm{~h}$ to $24 \mathrm{~h}$ as \% of the Wt or NT-siRNA control and are mean $\pm S D(n=6-9) .{ }^{* * *} p<0.001$ is considered statistically significant compared to the Wt or the NT-siRNA control.

To see whether the ERK and PI3K/Akt pathways, are involved in the increased migration and proliferation seen in Sk-2ko cells, we performed scratch assays and measured DNA synthesis of mouse mesangial cells in the absence or presence of inhibitors of these signaling pathways. Figure $5 \mathrm{~A}$ and $\mathrm{B}$ shows that the specific MEK inhibitor
U0126 (Wymann et al., 1996; Favata et al., 1998), but not the PI3K inhibitor wortmannin (Wymann et al., 1996) inhibited migration and proliferation of SK-2ko mMC.

Furthermore, it is well-known that small $\mathrm{G}$ proteins are important molecular regulators of cell migration and also proliferation (Hall, 1990). We therefore investigated 

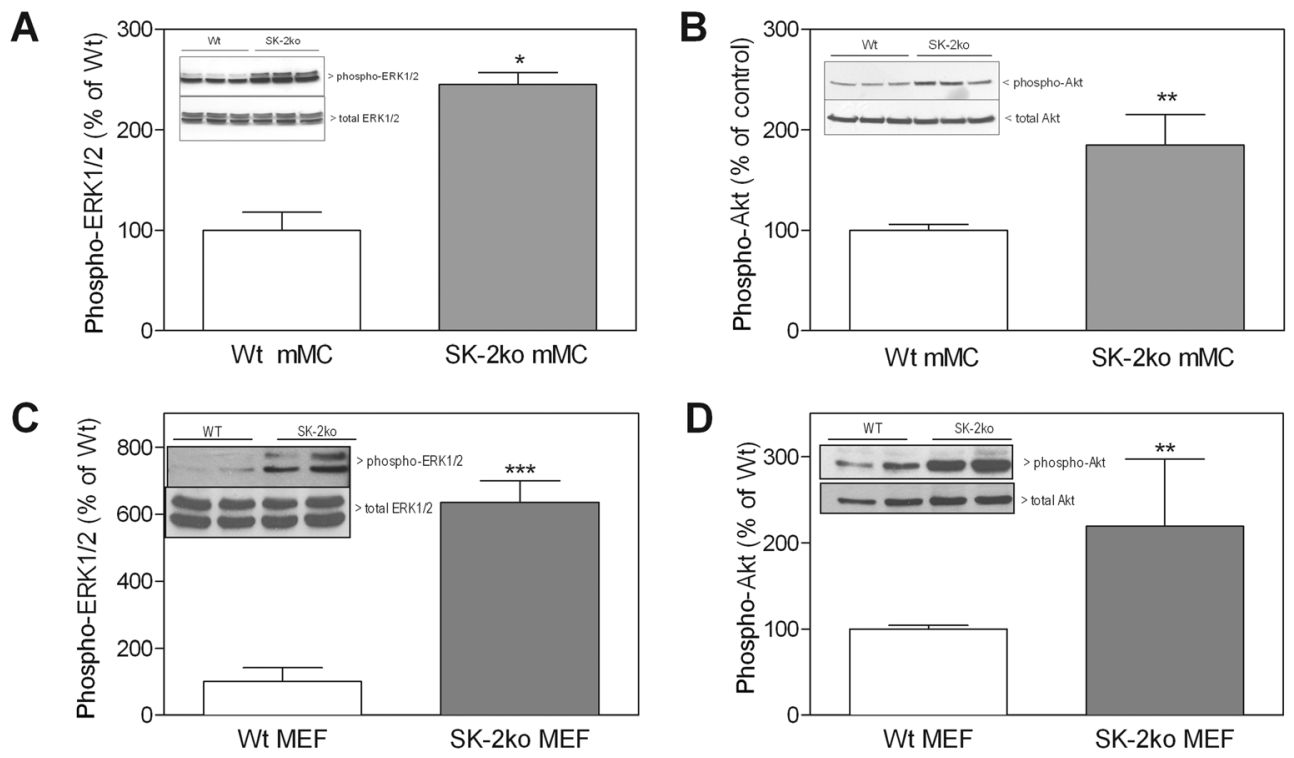

Figure 4: Effect of SK-2 deficiency on the activation state of ERK1/2 and PKB/Akt in mouse mesangial cells and fibroblasts.

Quiescent mouse mesangial cells (A, B) and mouse embryonic fibroblasts (C, D) isolated from either wild-type (Wt, white bars) or SK-2 deficient mice (SK-2ko, grey bars) were incubated for $6 \mathrm{~h}$ in DMEM containing $1 \% \mathrm{FBS}$. Thereafter, cell lysates containing $50 \mu \mathrm{g}$ of protein were separated by SDS-PAGE, transferred to nitrocellulose and subjected to Western blot analysis using antibodies against phospho-ERK1/2 and total ERK1/2 (A and C), and phospho-Ser ${ }^{473}$-PKB/Akt and total PKB/Akt1 (B, D). Bands were visualized by the ECL method according to the manufacturer's instructions and bands were densitometrically evaluated. Data are expressed as $\%$ of controls and are mean \pm SD $(\mathrm{n}=3) .{ }^{*} p<0.05,{ }^{* \star} p<0.01,{ }^{* \star \star} p<0.001$ considered statistically significant compared to the corresponding Wt values. The insets show representative immunoblots.

whether small G proteins are altered in SK-2ko cells. Small $\mathrm{G}$ protein activity was measured by G-LISA ${ }^{\circledast}$, which specifically detect the activated forms of the indicated small G proteins (Keely et al., 2007). As shown in Figure 6, basal RhoA activity was significantly increased in SK-2ko mesangial cells and this was further enhanced after S1P treatment. In contrast, Ras, Rac and cdc42 were not altered in SK-2ko mesangial cells (data not shown).

\section{Loss of SK-2 is associated with enhanced expression of SK-1 and the $\mathrm{S1}_{3}$ receptor}

In a next step, we tested both cell types for a possible compensatory upregulation of SK-1 expression. By using Western blot analysis, we indeed found an enhanced expression of SK-1 protein in SK-2ko mesangial cells and MEF. Even a partial and transient reduction of SK-2 with SK-2-siRNA resulted in a higher SK-1 protein expression compared to non-target siRNA transfected cells (Figure 7A). Furthermore, we screened the cells for S1P receptor subtype expression and, interestingly, found that in SK-2ko mMCs (Figure 7B) and MEFs (Figure 7C) S1P specifically was highly upregulated on the mRNA level.
When using SK-2 siRNA, we also observed an increased mRNA expression of $\mathrm{S}_{1} \mathrm{P}_{3}$ in comparison to the controltransfected cells (Figure 7D). In addition, we quantified cellular S1P in the cells and found that SK-2ko MEF contain significantly more cellular S1P than the wild-type cells (Figure 7F). Despite a similar upregulation of SK-1 protein in SK-2ko mesangial cells, the S1P concentration in whole-cell lipid extracts of mMCs did not vary between wild-type and SK-2ko cells (Figure 7E). Sphingosine and C16-ceramide accumulated in SK-2ko cells in both cell types (Figure 7E and F). To address if the altered S1P receptor expression profile affected cell motility, we performed a scratch migration assay in the presence of the S1P receptor antagonists W146 ( $\mathrm{S} 1 \mathrm{P}_{1}$ antagonist), JTE-013 ( $\mathrm{S} 1 \mathrm{P}_{2}$ antagonist) and $\mathrm{VPC} 23019$ ( $\mathrm{S}_{1 / 3}$ antagonist). Our data revealed that a significant reduction of cell migration was only detected in SK-2ko cells when using the S1P $\mathrm{P}_{1 / 3}$ inhibitor VPC23019, but not in the presence of W146, thus excluding a role of $\mathrm{S}_{1} \mathrm{P}_{1}$ in the increased migration capacity of SK-2ko cells (Figure 8). The $\mathrm{S}_{2} \mathrm{P}_{2}$ inhibitor JTE-013 enhanced the migratory response of wild-type and SK-2ko cells, thus demonstrating a potentially inhibitory role of $\mathrm{S} \mathrm{P}_{2}$ in mesangial cell migration (Figure 8 ). These data make it tempting to speculate that the observed enhanced 

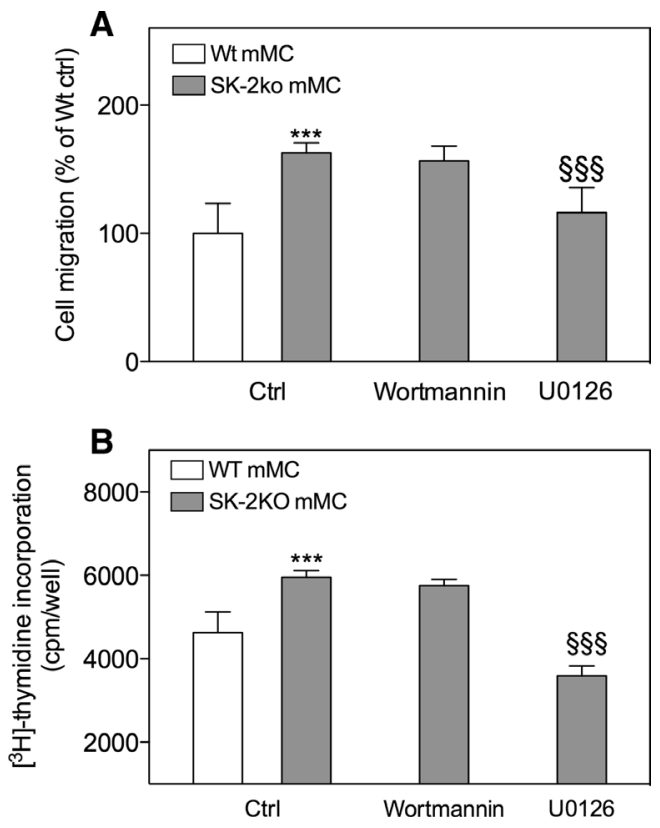

Figure 5: Involvement of the PI3K and ERK pathway in the SK2komediated increased migration and proliferation in mesangial cells. (A) Quiescent wild-type (Wt, white bar) or SK-2 deficient (SK-2ko, grey bars) mesangial cells (mMC) were subjected to a scratch and then allowed to recover for $24 \mathrm{~h}$ in DMEM containing $1 \% \mathrm{FBS}$ in the absence (Ctrl) or presence of wortmannin ( $200 \mathrm{nM})$ or U0126 $(10 \mu \mathrm{M})$. Light microscopy pictures were taken at time point $0 \mathrm{~h}$ and $24 \mathrm{~h}$ after the scratch and analyzed using the Image J software (Wayne Rasband, NIH, USA) by measuring the scratch area. Data are expressed as area reduction from time points $0 \mathrm{~h}$ to $24 \mathrm{~h}$ as \% of the Wt control and are mean \pm S.D. $(n=4)$. (B) Wild-type (Wt, white bars) or SK-2 deficient (SK-2ko, grey bars) mesangial cells (mMC) were plated and grown for the indicated time periods in growth medium supplemented with $\left.{ }^{3} \mathrm{H}\right]$ thymidine alone $(\mathrm{Ctrl})$ or in the presence of wortmannin $(200 \mathrm{nM})$ or U0126 $(10 \mu \mathrm{M})$ and processed as described in the Methods section. $\left[{ }^{3} \mathrm{H}\right]$ thymidine incorporated into DNA was measured in a $\beta$-counter. Data are expressed as $\mathrm{cpm} /$ well and are mean \pm SD $(n=4-6) .{ }^{* * *} p<0.001$ considered statistically significant compared the Wt ctrl, ${ }^{\S \S} p<0.001$ considered statistically significant compared to the SK-2ko ctrl value.

migration and proliferation of SK-2ko cells was the result of an autocrine $\mathrm{S} 1 \mathrm{P}$ action through the $\mathrm{S}_{1} \mathrm{P}_{3}$ receptor, although a further increase of S1P in renal mesangial cells seems dispensable.

Finally, we investigated the contribution of $\mathrm{S}_{3} \mathrm{P}_{3}$ to mesangial cell proliferation and migration by using cells isolated from $\mathrm{S}_{3} \mathrm{P}_{3}$ knockout mice. The data in Figure 9A show that the growth of $\mathrm{S}_{3} \mathrm{P}_{3} \mathrm{ko}$ mMCs in normal growth medium containing 10\% FBS was only slightly but still significantly reduced when compared to wild-type cells. When migration of these cells was analyzed in a scratch assay, we found that stimulation with S1P triggered increased migration in wild-type cells (Figure 9B), which

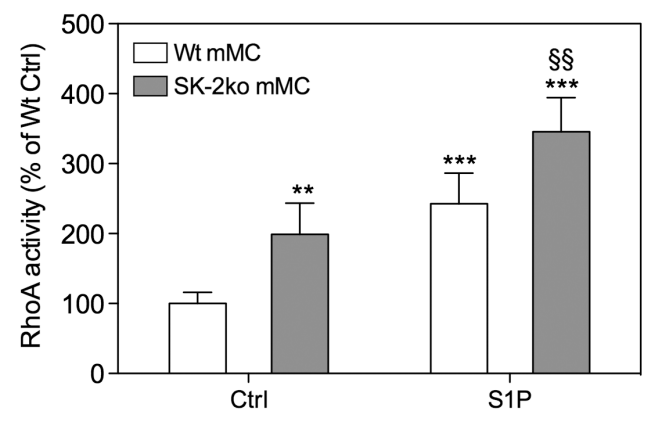

Figure 6: Effect of SK-2 deficiency on RhoA activity in mouse mesangial cells.

Quiescent mouse mesangial cells isolated from either wild-type (Wt, white bars) or SK-2 deficient mice (SK-2ko, grey bars) were stimulated for 10 min with either vehicle (Ctrl) or sphingosine 1-phosphate (S1P, $1 \mu \mathrm{M})$ in the presence of $1 \%$ FBS. Thereafter, cell lysates were subjected to G-LISA ${ }^{\circledR}$ RhoA activation assay according to the manufacturer's instructions. Data are expressed \% of Wt ctrl and are mean $\pm \mathrm{SD}(\mathrm{n}=3) .{ }^{* *} p<0.01,{ }^{* * *} p<0.001$ considered statistically significant compared to the vehicle treated Wt value, ${ }^{\S \S} p<0.01$ considered statistically significant compared to the S1P-stimulated Wt value.

was abolished in S1P ko cells (Figure 9B). In addition, the stimulation of RhoA activity by S1P detected in wildtype cells was clearly reduced in $\mathrm{S}_{3} \mathrm{P}_{3}$ ko cells (Figure 9C). Together, these data suggest that $\mathrm{S}_{1} \mathrm{P}_{3}$ indeed contributes to mesangial cell proliferation and migration.

\section{Discussion}

In this study we show for the first time that renal mesangial cells and embryonic fibroblasts isolated from SK-2 deficient mice have a higher capacity to proliferate and migrate when compared to wild-type cells. Since the successful cloning of SK-2 in 2000 (Liu et al., 2000a), the few published studies have reported rather controversial data on possible cellular functions of SK-2.

On the one hand, overexpression studies in various cell types revealed that SK-2 is localized in the nucleus and can inhibit DNA synthesis (Igarashi et al., 2003). Moreover, Liu et al. (2003) reported that overexpression of SK-2 had a pro-apoptotic effect on cells because of the existence of a BH3 domain that interacts with the anti-apoptotic factor Bcl- $\mathrm{X}_{\mathrm{L}}$ and thereby blocks Bcl- $\mathrm{X}_{\mathrm{L}}$ 's anti-apoptotic function. In line with this, our own previous studies revealed that a loss of SK-2 rendered mesangial cells less sensitive to stress-induced apoptosis (Hofmann et al., 2008).

On the other hand, SK-2 was activated by epidermal growth factor (EGF) (Hait et al., 2007) due to ERK-mediated 
A
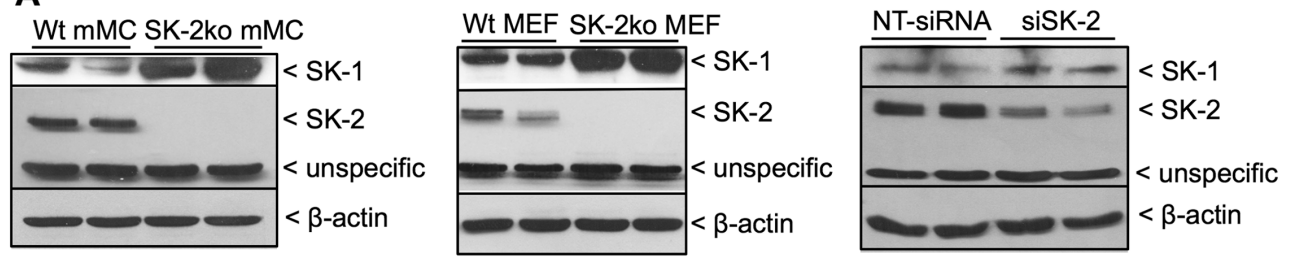

B

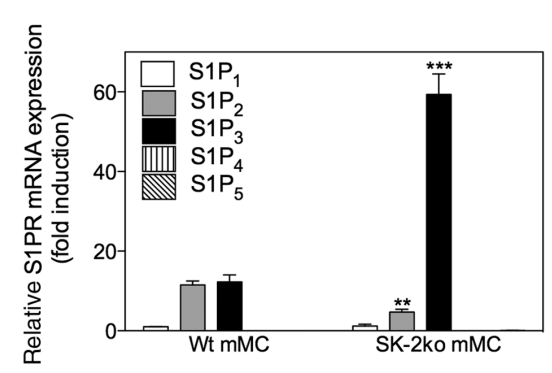

D

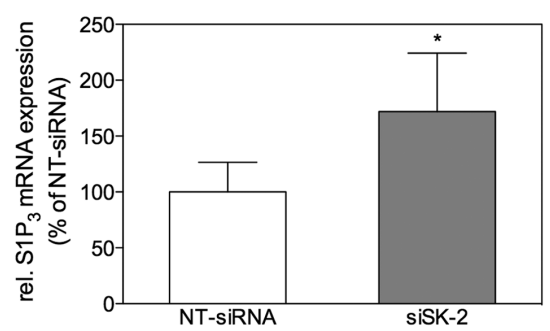

E

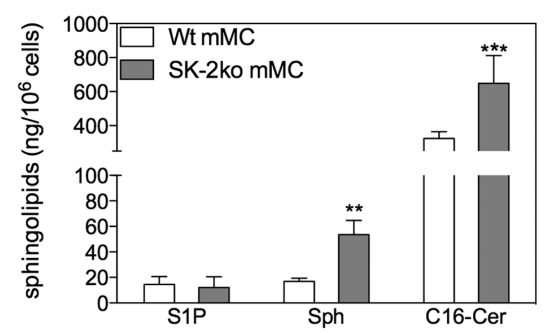

C

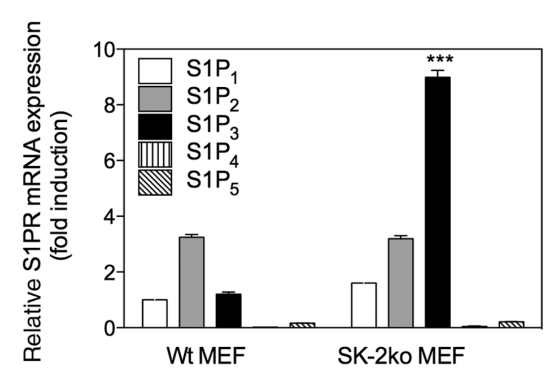

$\mathbf{F}$

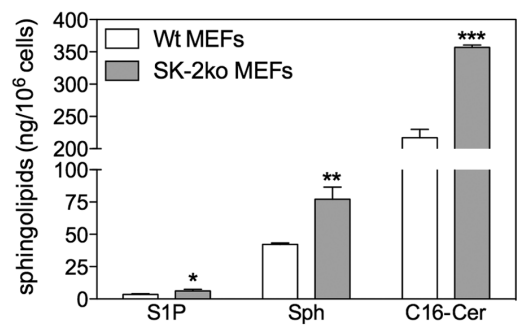

Figure 7: Effect of SK-2 deficiency on SK-1 protein expression, S1P receptor subtype mRNA expression, and on cellular sphingolipid levels in mouse mesangial cells and embryonic fibroblasts.

(A) Quiescent mouse mesangial cells and mouse embryonic fibroblasts isolated from either C57BL/6 mice (Wt) or SK-2 deficient mice (SK$2 \mathrm{ko}$ ) or mouse mesangial cells transiently transfected with either non-target siRNA (NT-siRNA) or siRNA against SK-2 (siSK-2) were subjected to WB analysis using specific antibodies against SK-1 (upper panels), SK-2 (middle panels) or $\beta$-actin (lower panels). (B-D) Quiescent mouse mesangial cells (B) and mouse embryonic fibroblasts (C) isolated from either C57BL/6 mice (Wt) or SK-2 deficient mice (SK-2ko) or transiently transfected mouse mesangial cells with either non-target siRNA (D, NT-siRNA) or siRNA against SK-2 (D, siSK-2) were taken for RNA extraction and subjected to quantitative $\mathrm{PCR}$ analysis using mouse primers of $\mathrm{S}_{1} \mathrm{P}_{1-5}(\mathrm{~B}, \mathrm{C})$ or $\mathrm{S}_{1} \mathrm{P}_{3}(\mathrm{D})$ as described in the Methods section. Data were obtained according to the $\Delta \Delta C_{T}$ method and are expressed as fold induction of $\mathrm{S1P}_{1}$ expression level (B, C) or as\% of NT-siRNA (D) and are mean \pm SD $(n=3-4) .{ }^{*} p<0.05,{ }^{* *} p<0.01,{ }^{* * *} p<0.001$ considered statistically significant compared to the corresponding Wt values. (E, F) Lipids were extracted from quiescent mouse mesangial cells (E) and mouse embryonic fibroblasts (F) from wild-type (Wt, white bars) and SK-2 deficient mice (SK-2ko, grey bars) and taken for LC-MS/MS to quantify sphingosine 1-phosphate (S1P), sphingosine (Sph) and C16-ceramide (C16-Cer). Results are expressed as ng lipid per $10^{6}$ cells and are mean $\pm \mathrm{SD}(\mathrm{n}=3) .{ }^{\star} p<0.05,{ }^{\star *} p<0.01,{ }^{\star \star *} p<0.001$ considered statistically significant compared to the corresponding Wt values.

hyperphosphorylation in breast cancer cells. Such an activation of SK-2 by growth factors is hardly consistent with a growth inhibiting and pro-apoptotic effect of SK-2.
In fact, we previously showed that in the breast cancer cell line MCF-7, EGF and estrogen rather down-regulated SK-2 mRNA expression (Döll et al., 2005, 2007), which 


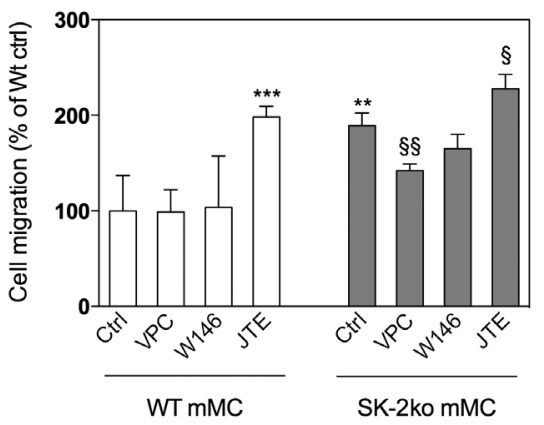

Figure 8: Effect of S1P receptor antagonists on the increased migration of mouse mesangial cells.

Quiescent wild-type (Wt, white bars) or SK-2 deficient (SK-2ko, grey bars) mesangial cells ( $\mathrm{mMC}$ ) were subjected to a scratch and then allowed to recover for $24 \mathrm{~h}$ in DMEM containing $1 \%$ FBS in the presence of either vehicle (Ctrl) or VPC23019 (VPC, $10 \mu \mathrm{M})$, W146 $(10 \mu \mathrm{M})$ or JTE-013 (JTE, $10 \mu \mathrm{M})$. Light microscopy pictures were taken at time point $0 \mathrm{~h}$ and $24 \mathrm{~h}$ after the scratch and analyzed using the Image J software (Wayne Rasband, NIH, USA) by measuring the scratch area. Data are expressed as area reduction from time points $0 \mathrm{~h}$ to $24 \mathrm{~h}$ as $\%$ of the Wt ctrl and are mean \pm SD $(n=4)$. ${ }^{* *} p<0.01,{ }^{* \star *} p<0.001$ considered statistically significant compared to the Wt ctrl, ${ }^{\S \S} p<0.01$ considered statistically significant compared to the SK-2ko ctrl value.

occurred concomitantly to an upregulation of SK-1 by these factors.

Recently, a catalytic inhibitor of SK-2 ABC294640 (French et al., 2010; Antoon et al., 2011) was developed and used to investigate the cellular function of SK-2. Although the in vitro $\mathrm{IC}_{50}$ for SK-2 was rather high with $50 \mu \mathrm{M}$ (French et al., 2010), oral administration of ABC294640 to mice bearing mammary adenocarcinoma xenografts resulted in a dose-dependent antitumor activity associated with depletion of S1P levels in the tumors and progressive tumor cell apoptosis (French et al., 2010; Antoon et al., 2011). These data suggested that SK-2 similar to SK-1 also drives cancer growth and progression. In the present study, treatment of mesangial cells with 30 and $100 \mu \mathrm{M} \mathrm{ABC294640} \mathrm{decreased} \mathrm{proliferation,} \mathrm{which,}$ however, was also detected in SK-2ko cells (Figure 2C). These data clearly demonstrate that ABC294640 elicits an anti-proliferative effect independent of SK-2 inhibition, thereby questioning the specificity of $\mathrm{ABC} 294640$. Recently, ABC294640 was shown to exert anti-estrogenic effects by directly antagonising estrogen receptor (ER) activation (Antoon et al., 2010). Molecular modelling studies revealed a direct docking of ABC294640 into the ligand binding site of the ER $\alpha$. This estrogen antagonistic potential may explain on the one hand the anti-proliferative effect and on the other hand why especially estrogen-sensitive breast cancer cells were strongly affected by the compound. The comparison of in vivo effects of
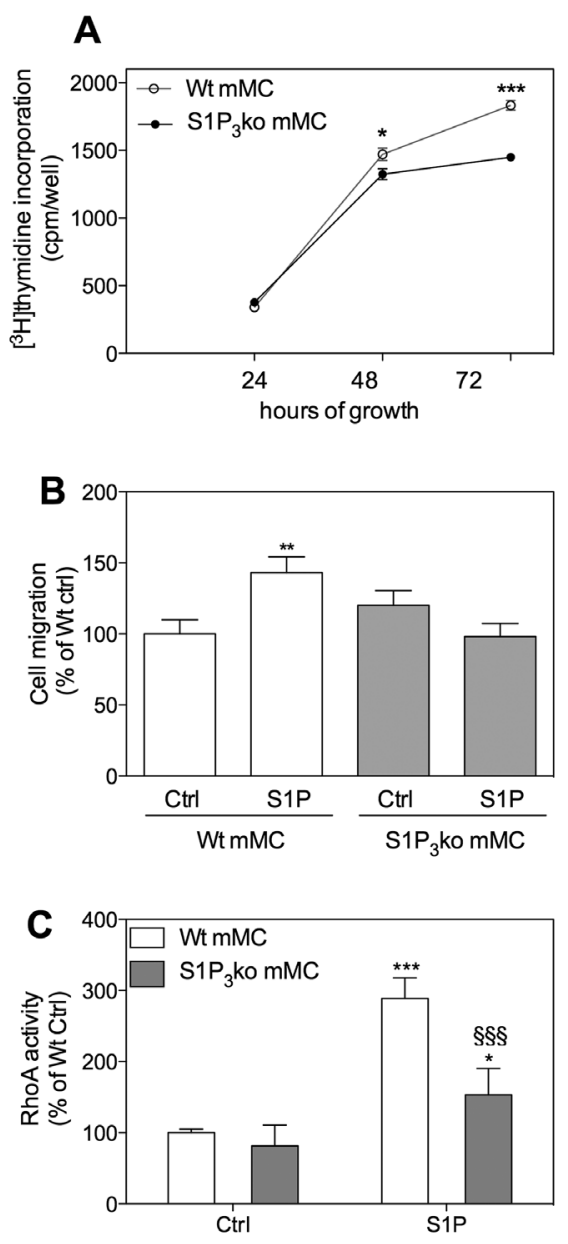

Figure 9: Effect of $\mathrm{S}_{1} \mathrm{P}_{3}$ knockout on proliferation and migration of mouse mesangial cells.

(A) $10^{5}$ mesangial cells isolated from either BalbC mice (Wt, empty circles) or $\mathrm{S}_{\mathrm{P}_{3}}$-deficient mice ( $\mathrm{S}_{3} \mathrm{P}_{3} \mathrm{ko}$, black circles) were plated and grown for the indicated time periods in growth medium supplemented with $\left[{ }^{3} \mathrm{H}\right]$ thymidine and processed as described in the Methods section. $\left.{ }^{3} \mathrm{H}\right]$ thymidine incorporated into DNA was measured in a $\beta$-counter. Data are expressed as cpm/well and are mean $\pm S D(n=3)$. ${ }^{\star} p<0.05,{ }^{\star * \star} p<0.001$ considered statistically significant compared to the corresponding control values. (B) Quiescent control mouse mesangial cells (Wt, white bars) or $\mathrm{S} \mathrm{P}_{3}$-deficient mesangial cells $\left(\mathrm{S}_{\mathrm{P}} \mathrm{k}_{3} \mathrm{k}\right.$, grey bars) were subjected to a scratch and allowed to recover for $24 \mathrm{~h}$ in DMEM containing $1 \%$ FBS the presence of either vehicle (Ctrl) or S1P $(1 \mu \mathrm{M})$. Light microscopy pictures were taken at time point $0 \mathrm{~h}$ and $24 \mathrm{~h}$ after the scratch and analyzed using the Image $\mathrm{J} \mathrm{software}$ (Wayne Rasband, NIH, USA) by measuring the scratch area. Data are expressed as area reduction from time points $0 \mathrm{~h}$ to $24 \mathrm{~h}$ as \% of the Wt ctrl value and are mean \pm SD $(n=4-6) .{ }^{* \star} p<0.01$ considered statistically significant compared to the Wt ctrl value. (C) Quiescent mouse mesangial cells isolated from either BalbC mice (Wt, white bars) or

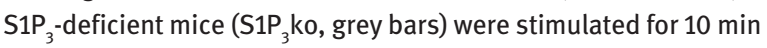
with either vehicle $(\mathrm{Ctrl})$ or sphingosine 1-phosphate (S1P, $1 \mu \mathrm{M})$ in the presence of $1 \%$ FBS. Thereafter, cell lysates were subjected to G-LISA ${ }^{\circledR}$ RhoA activation assay according to the manufacturer's instructions. Data are expressed as \% of Wt ctrl value and are mean $\pm S D(n=4)$. ${ }^{\star} p<0.05,{ }^{\star \star \star} p<0.001$ considered statistically significant compared to the vehicle treated Wt value, ${ }^{\S \S \S} p<0.001$ considered statistically significant compared to the S1P stimulated Wt value. 
ABC294640 with the effect of genetic SK-2 knockout mice also revealed inconsistent results. Whereas the inhibitor aggravated inflammatory arthritis, SK-2 knockout mice showed no change of disease severity compared to wildtype mice (Baker et al., 2013). Moreover, Liang et al. (2013) showed that SK-2 deficient mice develop more severe chronic intestinal inflammation and colitis-associated cancer, which, in terms of mechanism, was proposed to involve a counter-upregulation of SK-1 and S1P.

Our study also showed a compensatory upregulation of SK-1 protein in SK-2ko cells and SK-2-siRNA transfected cells, although the exact mechanisms leading to the observed enhanced SK-1 expression are not known. However, using LC-MS/MS we detected a rise of cellular S1P only in SK-2ko MEF but not in SK-2ko mMCs. The reason for this discrepancy might be the result of a detection limit, as we only measured S1P in whole-cell lipid extracts but not in subcellular fractions. Another possibility is that produced S1P is secreted more efficiently from mesangial cells than from fibroblasts. However, so far we were not able to measure an increased level in cell culture supernatants (data not shown). Further experiments are needed to clarify this issue.

In addition, our data revealed that specifically the $\mathrm{S}_{3} \mathrm{P}_{3}$ receptor was upregulated upon loss of SK-2 (Figure 7B-D). We therefore speculate that increased proliferation and migration observed in SK-2ko cells may be due to this enhanced $\mathrm{S}_{1} \mathrm{P}_{3}$ expression. We obtained evidence that $\mathrm{S}_{1} \mathrm{P}_{3}$ is involved in mesangial cell migration and proliferation from $\mathrm{S}_{3} \mathrm{P}_{3}$ knockout mesangial cells as (i) the $\mathrm{S}_{3} \mathrm{P}_{3}$ ko cells showed a slower proliferation rate in comparison to wildtype cells (Figure 9A) and (ii) S1P was able to induce cell migration only in wild-type but not in $\mathrm{S}_{3} \mathrm{P}_{3}$ ko cells (Figure 9B). Furthermore, the $\mathrm{S}_{1} \mathrm{P}_{1 / 3}$ antagonist VPC23019, but not the $\mathrm{S}_{1} \mathrm{P}_{1}$ antagonist $\mathrm{W} 146$, reduced migration in $\mathrm{mMC}$. This effect was only observed in SK-2ko cells, which showed a higher $\mathrm{S1P}_{3}$ mRNA expression, and not in Wt cells (Figure 8). However, as mesangial cell proliferation was only partially reduced in $\mathrm{S}_{1} \mathrm{P}_{3}$-deficient cells and also showed normal migration behavior under control conditions, we conclude that other receptor subtypes are involved too. Katsuma et al. reported that extracellular S1P triggers mesangial cell proliferation by involving both $\mathrm{S}_{2} \mathrm{P}_{2}$ and $\mathrm{S}_{1} \mathrm{P}_{3}$ (Katsuma et al., 2002). Similarly, proliferation of hepatoma cells (An et al., 2000) and satellite cells (Calise et al., 2012) also depended on both $\mathrm{S}_{1} \mathrm{P}_{2}$ and $\mathrm{S}_{1} \mathrm{P}_{3}$. Concerning cell migration, we observed an increased migration of mesangial cells when inhibiting the $\mathrm{S}_{1} \mathrm{P}_{2}$ receptor with JTE013, suggesting a potentially inhibitory role of $\mathrm{S}_{2} \mathrm{P}_{2}$ in cell migration, which was previously also reported in other cell types (Osada et al., 2002; Arikawa et al., 2003; Goparaju et al., 2005).
Similar to $\mathrm{S}_{2} \mathrm{P}_{2}$, the involvement of $\mathrm{S} \mathrm{P}_{3}$ in a migratory event is also conflicting. In this respect, Okamoto et al. (2000) showed that overexpression of $\mathrm{S}_{1} \mathrm{P}_{1}$ and $\mathrm{S}_{1} \mathrm{P}_{3}$ in Chinese hamster ovary (CHO) cells resulted in more S1Pstimulated migration. A similar situation was reported for human endothelial cells where S1P-triggered migration was abolished by antisense oligonucleotides against $\mathrm{S}_{1} \mathrm{P}_{1}$ and $\mathrm{S}_{3} \mathrm{P}_{3}$ (Paik et al., 2001), and in lung cancer cells where either a S1P ${ }_{3}$ knockdown by RNAi or Rho kinase inhibition by a catalytic inhibitor prevented a S1P-stimulated migratory/invasive response (Zhang et al., 2013).

By generating S1P receptor knockout mice, it turned out that $\mathrm{S1P}_{1}$ deficiency is embryonically lethal, as vascular maturation failed due to a defect in smooth muscle cells migration (Liu et al., 2000b). Consistently, embryonic fibroblasts (MEF) isolated from these $\mathrm{S1P}_{1}$ deficient mice also exhibited a defect in chemotaxis towards S1P (Liu et al., 2000b). These data clearly support an in vivo relevant function of $\mathrm{S}_{1} \mathrm{P}_{1}$ in smooth muscle cell and fibroblast migration. In contrast, $\mathrm{S}_{1} \mathrm{P}_{3}$ deficient mice showed no vascular maturation deficit, suggesting that $\mathrm{S}_{1} \mathrm{P}_{3}$ is not involved in smooth muscle cell migration and consequently vessel maturation (Liu et al., 2000b; Ishii et al., 2001).

Although these data do not allow a general conclusion, they somehow stress the possibility that $\mathrm{S}_{1} \mathrm{P}_{3}$, likely in cooperation with $\mathrm{S}_{1} \mathrm{P}_{1}$, is involved in S1P-stimulated cell migration in a cell-type specific manner.

Our data further demonstrate that not only the basal but also the S1P-stimulated RhoA activity is enhanced in SK-2 deficient cells. RhoA is one of three members of the Rho GTPase family that plays a crucial role in the regulation of cell migration. There seems to be a spatiotemporal dynamic of RhoA action driving not only membrane protrusions at the leading edge of the cells but also tail retraction (Pertz et al., 2006). Although previously regarded as an anti-migratory GTPase, the finding that RhoA localizes at the leading edge of cells where it is important for membrane ruffling and lamellae formation confirms other studies describing RhoA as pro-migratory factor (for review, see O'Connor and Chen, 2013). As we were only able to measure RhoA activity in whole-cell lysates, we cannot decipher the exact cellular localization of the enhanced RhoA activity in SK-2ko cells to allow a final conclusion on the specific impact of RhoA acting pro-migratory on the leading edge or anti-migratory by tail retraction in mesangial cells. However, RhoA is activated by extracellular S1P in many cell types including CHO cells (Okamoto et al., 2000), endothelial cells (Paik et al., 2001), and bladder cancer cells (vom Dorp et al., 2011), and this seems to be mandatory for cell migration. 
It is tempting to speculate that both $\mathrm{S}_{2} \mathrm{P}_{2}$ and $\mathrm{S}_{1} \mathrm{P}_{3}$ receptors cooperatively orchestrate cell migration. All these data suggest that it is well conceivable that an enhanced SK-1/S1P ${ }_{3} /$ RhoA signaling contributes to the increased migration of SK-2ko cells.

Notably, in SK-2ko cells there was a much more pronounced increase of sphingosine and C16-ceramide compared to S1P (Figures 7E and 7F), supporting speculations whether another sphingolipid mediator besides S1P contributes to the effects observed in this study. In this regard, we and others have shown that ceramide can directly bind to and activate c-Raf (Huwiler et al., 1996), PKC- $\alpha$ (Huwiler et al., 1998) and PKC- $\zeta$ (Muller et al., 1995) but inhibit PKC- $\delta$ (Huwiler et al., 1998; Bessa et al., 2013). Further studies are needed to evaluate the exact contribution of the various sphingolipid-derived mediators to the observed phenotype of SK-2ko mesangial cells.

Although our study has only addressed the effect of SK-2ko in mesangial cells, it will be interesting to see whether in vivo in a renal disease model SK-2 deficient mice also respond with increased proliferation and migration. In this context, in a renal ischemia/reperfusion injury (IRI) model in SK-2ko mice it was reported that loss of SK-2 led to more severe kidney injury as indicated by elevated plasma creatinine levels, increased tubular cell necrosis, dilation of tubules, and cast formation in the outer medulla. In addition, kidneys of IRI-exposed SK-2ko mice not only showed more neutrophil infiltration but remarkably also increased ${\mathrm{S} 1 \mathrm{P}_{3}}_{3}$ expression (Jo et al., 2009), which supports our data obtained in renal mesangial cells and fibroblasts.

Altogether, our data show for the first time that loss of SK-2 in renal mesangial cells and fibroblasts may have considerable impact on cell growth and migration, and that SK-2 exerts a suppressive effect on these cellular responses that are crucial in many renal diseases, such as renal cancer and chronic inflammatory kidney diseases.

\section{Materials and methods}

\section{Chemicals}

[6-3 $\left.{ }^{-3}\right]$ methyl-thymidine (specific activity: $14.5 \mathrm{Ci} / \mathrm{mmol}$ was from American Radiolabeled Chemicals Inc., St. Louis, MO, USA. The secondary anti-rabbit and anti-mouse horseradish peroxidasecoupled antibodies, HyperfilmMP and the enhanced chemiluminescence (ECL) reagents were from GE Health Care Systems GmbH, Freiburg, Germany. Sphingolipid standards for LC/MS, W146, JTE013 and VPC23019 were from Avanti Polar Lipids Inc., Alabaster, AL, USA; U0126, and wortmannin were from Merck Biosciences, Schwalbach, Germany. Antibodies against phospho-Ser ${ }^{473}$-PKB/Akt,
phospho-ERK1/2, total Akt, and total ERK1/2 were from Cell Signaling, Frankfurt, Germany; the $\beta$-actin antibody (clone AC-15), DAPI, were from Sigma Aldrich Fine Chemicals, St. Louis, MO, USA. RhoA G-lisa was from Cytoskeleton Inc., CO, USA. All cell culture media and supplements were from Invitrogen, Allschwil, Switzerland.

\section{Peptide synthesis and antibody generation for SK-1 and SK-2 antibodies}

Peptide synthesis and antibody generation was performed by Eurogentec s.a. (Seraing, Belgium). Two synthetic peptides based on the sequence of the mouse SK-1 (accession number: NM_011451) (-CPS GRD SRR GPP PEE P-COOH and -LEP RSQ-RGV FSV DGE C-CONH ${ }_{2}$ ) or on the sequence of the mouse SK-2 (accession number: NM_020011) (-CTL LTG PAG QKP QA-COOH and -CPI AEG PPE MPA SSG F-CONH ${ }_{2}$ ) were synthesized and coupled to keyhole-limpet hemocyamin, and used to immunize two rabbits. The antibodies from terminal bleeds were purified by affinity chromatography by using an anti-peptidecoupled sepharose column.

\section{Cell culture}

Primary cultures of mouse renal mesangial cells were isolated from C57BL/6 mice (Wt) or SK-2 knockout (ko) mice exactly as previously described (Klawitter et al., 2007; Hofmann et al., 2008). Outgrown mesangial cells were subcultured and further used up to passage 20. Cells were cultured in RPMI medium containing 15\% FBS, $10 \mathrm{~mm}$ HEPES, pH 7.4, 100 units $/ \mathrm{ml}$ penicillin, $100 \mu \mathrm{g} / \mathrm{ml}$ streptomycin, $6 \mu \mathrm{g} / \mathrm{ml}$ bovine insulin, $5 \mu \mathrm{g} / \mathrm{ml}$ transferrin, $5 \mathrm{ng} / \mathrm{ml}$ sodium selenite, $4.5 \mu \mathrm{g} / \mathrm{ml} \beta$-mercaptoethanol. Mouse embryonic fibroblasts (MEF) were isolated from C57BL6 mice or SK-2 deficient mice as previously described (Conner, 2001). Cells were cultured in Dulbecco's modified Eagle medium (DMEM) containing 10\% FBS, 10 mM HEPES, pH 7.4, 100 units $/ \mathrm{ml}$ penicillin, $100 \mu \mathrm{g} / \mathrm{ml}$ streptomycin.

\section{siRNA transfection}

siRNA transfection was conducted by using the Amaxa ${ }^{\mathrm{TM}}$ Mouse/Rat Hepatocyte Nucleofector ${ }^{\mathrm{TM}}$ Kit (Lonza, Cologne, Germany) according to the Amaxa ${ }^{\mathrm{TM}}$ protocol for mouse embryonic fibroblasts. Briefly, mouse mesangial cells were harvested by trypsinization, centrifuged and resuspended in $100 \mu \mathrm{l}$ Nucleofector ${ }^{\mathrm{TM}}$ solution. After addition of either $0.5 \mu \mathrm{M}$ non-target siRNA (Thermo Fisher Scientic, Waltham, MA, USA) or $0.5 \mu$ M SK-2 siRNA (antisense sequence: GCC CUA CAC AUA CAG CGA C) transfection was performed in a cuvette using protocol N-024. The cells were immediately transferred to the culture plate and cultured at $37^{\circ} \mathrm{C}$ for $1-2$ days prior to use in further experiments.

\section{Cell stimulation and Western blot analysis}

Confluent cells in $100 \mathrm{~mm}$ diameter dishes were rendered quiescent by incubating for $24 \mathrm{~h}$ in DMEM containing $0.1 \mathrm{mg} / \mathrm{ml}$ of fatty acidfree bovine serum albumin (BSA). Thereafter, cells were treated as 
indicated. To stop the stimulation, the medium was withdrawn and cells were homogenized as previously described (Rölz et al., 2002). Equal amounts of protein were separated by SDS-PAGE, transferred to nitrocellulose membranes, and subjected to Western blot analysis as previously described (Rölz et al., 2002).

\section{Transwell migration assay}

Cell migration was measured by using an adapted Boyden chamber assay. In brief, the ability of cells to migrate through a Transwell filter ( $6.5 \mathrm{~mm}$ diameter, $8 \mu \mathrm{M}$ pore size) was analyzed. After serum starvation, cells were detached by trypsinization and seeded into Transwell filters at $1 \times 10^{5}$ cells in $100 \mu \mathrm{l}$ starvation medium. $500 \mu \mathrm{l}$ of starvation medium were placed in the lower compartment and the cells were left to migrate for the indicated time periods. Thereafter, the Transwell filters were removed and processed as previously described (Huwiler et al., 2006). Migrated cells were determined by counting the DAPIstained cells on the filters in five random areas per sample using a fluorescence microscope.

\section{Scratch assay for cell migration}

Equal number of cells were seeded in growth medium in PS35 and cultured for $6 \mathrm{~h}$ to allow adherence followed by a starvation period in DMEM containing $1 \%$ of FBS for $18 \mathrm{~h}$. Thereafter, a 'scratch' was created on the confluent cell monolayer using a p200 pipet tip and the dish was immediately photographed under a phase-contrast microscope at specific reference points. A second image was taken $24 \mathrm{~h}$ after previous alignment along the reference points to ensure assessment of the same scratch area. The images were analyzed using the Image J software (Wayne Rasband, NIH, USA) by measuring the scratch area at $0 \mathrm{~h}$ and $24 \mathrm{~h}$ after incubation. Data are expressed as area reduction from time points $0 \mathrm{~h}$ to $24 \mathrm{~h}$.

\section{$\left[{ }^{3} \mathrm{H}\right]$ Thymidine incorporation}

5000 cells were plated per well of a 24-well plate and incubated for $20 \mathrm{~h}$. Thereafter, cells were incubated in growth medium containing $0.2 \mu \mathrm{Ci} / \mathrm{ml}$ of $\left[{ }^{3} \mathrm{H}\right]$ methyl-thymidine. After different time periods, the medium was removed and cells were washed twice with PBS and incubated with ice-cold 5\% trichloroacetic acid (TCA) for $30 \mathrm{~min}$. Cells were washed twice with 5\% TCA, the DNA was solubilized in $1 \mathrm{M} \mathrm{NaOH}$ for $30 \mathrm{~min}$ at $37^{\circ} \mathrm{C}$, and the radioactivity was counted in a $\beta$-counter.

\section{Quantitative PCR analysis}

Real-time PCR was performed using SYBRgreen ${ }^{\circledR}$ and a BioRad iQ iCycler Detection System. Primer sequences were as follows. Mouse S1P: forward: CTG ACC TTC CGC AAG AAC ATC T; reverse: CTT CAG CAA GGC CAG AGA CTT C; mouse $\mathrm{S1P}_{2}$ : forward: GAG CTC ATC ACC TCT TCA TCC TAT C; reverse: GAA GAT GCA GTA AGA GTA CCC AGG A; mouse S1P 3 : forward: TGT AGC TTC ATC GTC GTC TTG GAG; reverse:
GCC GAT GAA AAA GTA CAT GCG G; mouse $\mathrm{S1P}_{4}$ : forward: GGC TAC TGG CAG CTA TCC TG; reverse: AAG GCC ACC AAG ATC ATC AG; mouse $\mathrm{S1P}_{5}$ : forward: GGA GGG ACT CTC CTG GAT TC; reverse: TTC CTC TGT AGC CAG CCA CT. IQ ${ }^{\mathrm{TM}} 5$ Optical System Software (Version 2.0) was used to analyze real-time and endpoint fluorescence. One microgram of total RNA isolated with TRIZOL ${ }^{\circledR}$ reagent was used for reverse transcriptase-PCR (First Strand Synthesis Kit, MBI Fermentas, St-Leon-Roth, Germany); a random hexamer primer was utilized for amplification. The fold induction values were obtained using to the $\Delta \Delta C_{\mathrm{T}}$ method, after normalization to the housekeeping gene $18 \mathrm{~S}$ RNA.

\section{RhoA activity assay}

The activity of the small $\mathrm{G}$ protein RhoA was determined by using a specific G-LISA ${ }^{\mathrm{TM}}$ activity assay kit (Cytoskeleton Inc., Denver, CO, US) exactly as described in the manufacturer's manual.

\section{Lipid quantification by mass spectrometry}

Confluent cells in PS35 wells were either taken for lipid extraction and LC-MS/MS analysis exactly as previously described (Hofmann et al., 2008) or taken for cell counting for lipid equalization.

\section{Statistical analysis}

Statistical analysis was performed by unpaired $t$-test and two-tailed $p$-values for the comparison of two groups, and by one-way analysis of variance (ANOVA) with Bonferroni post-test for the comparison of three and more groups.

Acknowledgments: This work was supported by the Swiss National Science Foundation (3100A0-111806), and the German Research Foundation (SFB1039/TP02). We thank Isolde Römer and Simone Albert for technical assistance.

\section{References}

Alemany, R., van Koppen, C.J., Danneberg, K., Ter Braak, M., and Meyer Zu Heringdorf, D. (2007). Regulation and functional roles of sphingosine kinases. Naunyn-Schmiedeberg's Arch. Pharmacol. 374, 413-428.

An, S., Zheng, Y., and Bleu, T. (2000). Sphingosine 1-phosphateinduced cell proliferation, survival, and related signaling events mediated by $\mathrm{G}$ protein-coupled receptors Edg3 and Edg5. J. Biol. Chem. 275, 288-296.

Antoon, J.W., White, M.D., Meacham, W.D., Slaughter, E.M., Muir, S.E., Elliott, S., Rhodes, L.V., Ashe, H.B., Wiese, T.E., Smith, C.D., et al. (2010). Antiestrogenic effects of the novel sphingosine kinase-2 inhibitor ABC294640. Endocrinology 151, 5124-5135. 
Antoon, J.W., White, M.D., Slaughter, E.M., Driver, J.L., Khalili, H.S., Elliott, S., Smith, C.D., Burow, M.E., and Beckman, B.S. (2011). Targeting NF-kB mediated breast cancer chemoresistance through selective inhibition of sphingosine kinase-2. Cancer Biol. Ther. 11, 678-689.

Arikawa, K., Takuwa, N., Yamaguchi, H., Sugimoto, N., Kitayama, J., Nagawa, H., Takehara, K., and Takuwa, Y. (2003). Liganddependent inhibition of B16 melanoma cell migration and invasion via endogenous S1P2 G protein-coupled receptor. Requirement of inhibition of cellular RAC activity. J. Biol. Chem. 278, 32841-32851.

Baker, D.A., Eudaly, J., Smith, C.D., Obeid, L.M., and Gilkeson, G.S. (2013). Impact of sphingosine kinase 2 deficiency on the development of TNF-a-induced inflammatory arthritis. Rheumatol. Int. 33, 2677-2681.

Bessa, C., Pereira, C., Leao, M., Maciel, C., Gomes, S., Goncalves, J., Corte-Real, M., Costa, V., and Saraiva, L. (2013). Using yeast to uncover the regulation of protein kinase Cdelta by ceramide. FEMS Yeast Res. 13, 700-705.

Calise, S., Blescia, S., Cencetti, F., Bernacchioni, C., Donati, C., and Bruni, P. (2012). Sphingosine 1-phosphate stimulates proliferation and migration of satellite cells: role of S1P receptors. Biochim. Biophys. Acta. 1823, 439-450.

Conner, D.A. (2001). Mouse embryo fibroblast (MEF) feeder cell preparation. Curr. Protoc. Mol. Biol. Chapter 23, Unit 2322.

Döll, F., Pfeilschifter, J., and Huwiler, A. (2005). The epidermal growth factor stimulates sphingosine kinase-1 expression and activity in the human mammary carcinoma cell line MCF7. Biochim. Biophys. Acta. 1738, 72-81.

Döll, F., Pfeilschifter, J., and Huwiler, A. (2007). Prolactin upregulates sphingosine kinase- 1 expression and activity in the human breast cancer cell line MCF7 and triggers enhanced proliferation and migration. Endocr. Relat. Cancer 14, 325-335.

Favata, M.F., Horiuchi, K.Y., Manos, E.J., Daulerio, A.J., Stradley, D.A., Feeser, W.S., Van Dyk, D.E., Pitts, W.J., Earl, R.A., Hobbs, F., et al. (1998). Identification of a novel inhibitor of mitogenactivated protein kinase kinase. J. Biol. Chem. 273, 1862318632.

French, K.J., Schrecengost, R.S., Lee, B.D., Zhuang, Y., Smith, S.N., Eberly, J.L., Yun, J.K., and Smith, C.D. (2003). Discovery and evaluation of inhibitors of human sphingosine kinase. Cancer Res. 63, 5962-5969.

French, K.J., Upson, J.J., Keller, S.N., Zhuang, Y., Yun, J.K., and Smith, C.D. (2006). Antitumor activity of sphingosine kinase inhibitors. J. Pharmacol. Exp. Ther. 318, 596-603.

French, K.J., Zhuang, Y., Maines, L.W., Gao, P., Wang, W., Beljanski, V., Upson, J.J., Green, C.L., Keller, S.N., and Smith, C.D. (2010). Pharmacology and antitumor activity of ABC294640, a selective inhibitor of sphingosine kinase-2. J. Pharmacol. Exp. Ther. 333, 129-139.

Goparaju, S.K., Jolly, P.S., Watterson, K.R., Bektas, M., Alvarez, S., Sarkar, S., Mel, L., Ishii, I., Chun, J., Milstien, S., et al. (2005). The S1P2 receptor negatively regulates platelet-derived growth factor-induced motility and proliferation. Mol. Cell. Biol. 25, 4237-4249.

Hait, N.C., Bellamy, A., Milstien, S., Kordula, T., and Spiegel, S. (2007). Sphingosine kinase type 2 activation by ERK-mediated phosphorylation. J. Biol. Chem. 282, 12058-12065.

Hall, A. (1990). The cellular functions of small GTP-binding proteins. Science 249, 635-640.
Hofmann, L.P., Ren, S., Schwalm, S., Pfeilschifter, J., and Huwiler, A. (2008). Sphingosine kinase 1 and 2 regulate the capacity of mesangial cells to resist apoptotic stimuli in an opposing manner. Biol. Chem. 389, 1399-1407.

Huwiler, A., Brunner, J., Hummel, R., Vervoordeldonk, M., Stabel, S., van den Bosch, H., and Pfeilschifter, J. (1996). Ceramidebinding and activation defines protein kinase c-Raf as a ceramide-activated protein kinase. Proc. Natl. Acad. Sci. USA 93, 6959-6963.

Huwiler, A., Doll, F., Ren, S., Klawitter, S., Greening, A., Romer, I., Bubnova, S., Reinsberg, L., and Pfeilschifter, J. (2006). Histamine increases sphingosine kinase-1 expression and activity in the human arterial endothelial cell line EA.hy 926 by a PKC-alpha-dependent mechanism. Biochim. Biophys. Acta. 1761, 367-376.

Huwiler, A., Fabbro, D., and Pfeilschifter, J. (1998). Selective ceramide binding to protein kinase $\mathrm{C}$-a and - $\mathrm{d}$ isoenzymes in renal mesangial cells. Biochemistry 37, 14556-14562.

Huwiler, A., Kolter, T., Pfeilschifter, J., and Sandhoff, K. (2000). Physiology and pathophysiology of sphingolipid metabolism and signaling. Biochim. Biophys. Acta. 1485, 63-99.

Huwiler, A. and Pfeilschifter, J. (2006). Altering the sphingosine1-phosphate/ceramide balance: a promising approach for tumor therapy. Curr. Pharm. Des. 12, 4625-4635.

Igarashi, N., Okada, T., Hayashi, S., Fujita, T., Jahangeer, S., and Nakamura, S. (2003). Sphingosine kinase 2 is a nuclear protein and inhibits DNA synthesis. J. Biol. Chem. 278, 46832-46839.

Ishii, I., Friedman, B., Ye, X., Kawamura, S., McGiffert, C., Contos, J.J., Kingsbury, M.A., Zhang, G., Brown, J.H., and Chun, J. (2001). Selective loss of sphingosine 1-phosphate signaling with no obvious phenotypic abnormality in mice lacking its $\mathrm{G}$ protein-coupled receptor, LP(B3)/EDG-3. J. Biol. Chem. 276, 33697-33704.

Jo, S.K., Bajwa, A., Ye, H., Vergis, A.L., Awad, A.S., Kharel, Y., Lynch, K.R., and Okusa, M.D. (2009). Divergent roles of sphingosine kinases in kidney ischemia-reperfusion injury. Kidney Int. 75, 167-175.

Katsuma, S., Hada, Y., Ueda, T., Shiojima, S., Hirasawa, A., Tanoue, A., Takagaki, K., Ohgi, T., Yano, J., and Tsujimoto, G. (2002). Signalling mechanisms in sphingosine 1-phosphate-promoted mesangial cell proliferation. Genes Cells 7, 1217-1230.

Keely, P.J., Conklin, M.W., Gehler, S., Ponik, S.M., and Provenzano, P.P. (2007). Investigating integrin regulation and signaling events in three-dimensional systems. Methods Enzymol. 426, 27-45.

Klawitter, S., Hofmann, L.P., Pfeilschifter, J., and Huwiler, A. (2007). Extracellular nucleotides induce migration of renal mesangial cells by upregulating sphingosine kinase- 1 expression and activity. Br. J. Pharmacol. 150, 271-280.

Kunkel, G.T., Maceyka, M., Milstien, S., and Spiegel, S. (2013). Targeting the sphingosine-1-phosphate axis in cancer, inflammation and beyond. Nat. Rev. Drug Discov. 12, 688-702.

Liang, J., Nagahashi, M., Kim, E.Y., Harikumar, K.B., Yamada, A., Huang, W.C., Hait, N.C., Allegood, J.C., Price, M.M., Avni, D., et al. (2013). Sphingosine-1-phosphate links persistent STAT3 activation, chronic intestinal inflammation, and development of colitis-associated cancer. Cancer Cell 23, 107-120.

Liu, H., Sugiura, M., Nava, V.E., Edsall, L.C., Kono, K., Poulton, S., Milstien, S., Kohama, T., and Spiegel, S. (2000a). Molecular cloning and functional characterization of a novel mammalian 
sphingosine kinase type 2 isoform. J. Biol. Chem. 275, 19513-19520.

Liu, Y., Wada, R., Yamashita, T., Mi, Y., Deng, C.X., Hobson, J.P., Rosenfeldt, H.M., Nava, V.E., Chae, S.S., Lee, M.J., et al. (2000b). Edg-1, the G protein-coupled receptor for sphingosine-1-phosphate, is essential for vascular maturation. J. Clin. Invest. 106, 951-961.

Liu, H., Toman, R.E., Goparaju, S.K., Maceyka, M., Nava, V.E., Sankala, H., Payne, S.G., Bektas, M., Ishii, I., Chun, J., et al. (2003). Sphingosine kinase type 2 is a putative BH3-only protein that induces apoptosis. J. Biol. Chem. 278, 40330-40336.

Muller, G., Ayoub, M., Storz, P., Rennecke, J., Fabbro, D., and Pfizenmaier, K. (1995). PKC zeta is a molecular switch in signal transduction of TNF-a, bifunctionally regulated by ceramide and arachidonic acid. EMBO J. 14, 1961-1969.

O'Connor, K. and Chen, M. (2013). Dynamic functions of RhoA in tumor cell migration and invasion. Small GTPases 4, 141-147.

Okada, T., Ding, G., Sonoda, H., Kajimoto, T., Haga, Y., Khosrowbeygi, A., Gao, S., Miwa, N., Jahangeer, S., and Nakamura, S. (2005). Involvement of N-terminal-extended form of sphingosine kinase 2 in serum-dependent regulation of cell proliferation and apoptosis. J. Biol. Chem. 280, 36318-36325.

Okamoto, H., Takuwa, N., Yokomizo, T., Sugimoto, N., Sakurada, S., Shigematsu, H., and Takuwa, Y. (2000). Inhibitory regulation of Rac activation, membrane ruffling, and cell migration by the $G$ protein-coupled sphingosine-1-phosphate receptor EDG5 but not EDG1 or EDG3. Mol. Cell. Biol. 20, 9247-9261.

Osada, M., Yatomi, Y., Ohmori, T., Ikeda, H., and Ozaki, Y. (2002). Enhancement of sphingosine 1-phosphate-induced migration of vascular endothelial cells and smooth muscle cells by an EDG-5 antagonist. Biochem. Biophys. Res. Commun. 299, 483-487.

Paik, J.H., Chae, S., Lee, M.J., Thangada, S., and Hla, T. (2001). Sphingosine 1-phosphate-induced endothelial cell migration requires the expression of EDG-1 and EDG-3 receptors and Rhodependent activation of avb3- and b1-containing integrins. J. Biol. Chem. 276, 11830-11837.
Pertz, O., Hodgson, L., Klemke, R.L., and Hahn, K.M. (2006). Spatiotemporal dynamics of RhoA activity in migrating cells. Nature 440, 1069-1072.

Pyne, N.J. and Pyne, S. (2010). Sphingosine 1-phosphate and cancer. Nat. Rev. Cancer 10, 489-503.

Rölz, W., Xin, C., Ren, S., Pfeilschifter, J., and Huwiler, A. (2002). Interleukin-1 inhibits angiotensin II-stimulated protein kinase $B$ pathway in renal mesangial cells via the inducible nitric oxide synthase. Eur. J. Pharmacol. 442, 195-203.

Ruckhäberle, E., Rody, A., Engels, K., Gaetje, R., von Minckwitz, G., Schiffmann, S., Grösch, S., Geisslinger, G., Holtrich, U., Karn, T., et al. (2008). Microarray analysis of altered sphingolipid metabolism reveals prognostic significance of sphingosine kinase 1 in breast cancer. Breast Cancer Res. Treat. 112, 41-52.

Shida, D., Takabe, K., Kapitonov, D., Milstien, S., and Spiegel, S. (2008). Targeting SphK1 as a new strategy against cancer. Curr. Drug Targets 9, 662-673.

Vivanco, I. and Sawyers, C.L. (2002). The phosphatidylinositol 3-Kinase AKT pathway in human cancer. Nat. Rev. Cancer 2, 489-501.

vom Dorp, F., Sanders, H., Boergermann, C., Lummen, G., Rubben, H., Jakobs, K.H., and Schmidt, M. (2011). Inhibition of Rho-kinase abrogates migration of human transitional cell carcinoma cells: results of an in vitro study. Urol. Int. 86, 220-227.

Wymann, M.P., Bulgarelli-Leva, G., Zvelebil, M.J., Pirola, L., Vanhaesebroeck, B., Waterfield, M.D., and Panayotou, G. (1996). Wortmannin inactivates phosphoinositide 3-kinase by covalent modification of Lys-802, a residue involved in the phosphate transfer reaction. Mol. Cell Biol. 16, 1722-1733.

Zhang, W., Zhao, J., Lee, J.F., Gartung, A., Jawadi, H., Lambiv, W.L., Honn, K.V., and Lee, M.J. (2013). ETS-1-mediated transcriptional up-regulation of CD44 is required for sphingosine-1-phosphate receptor subtype 3-stimulated chemotaxis. J. Biol. Chem. 288, 32126-32137. 